\title{
Disclosure theories and disclosure measures *
}

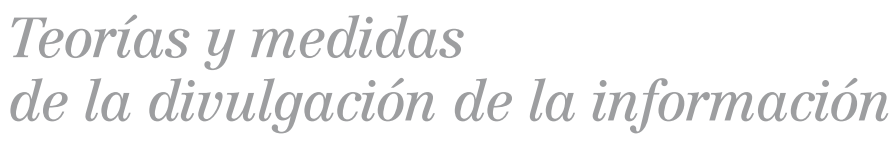

\author{
Francisco Bravo Urquiza** . Universidad de Sevilla \\ María Cristina Abad Navarro. Universidad de Sevilla \\ Marco Trombetta. Instituto de Empresa
}

\begin{abstract}
Theories have been developed in the disclosure literature to explain the reasons behind the decision to disclose more information. Empirical evidence does not consistently support disclosure theories and results found are contradictory. The difficulty in measuring voluntary disclosure might be one of the reasons influencing on these divergences. In this paper, we investigate two key questions related to disclosure measurement. First, we aim to empirically test if use of disclosure indices that measure different information attributes determines validity of disclosure theories. Second, we investigate how disclosure indices design influences results. Results show that determinants of more specific information attributes are different than those that influence less specific attributes. Furthermore, independently of the information attribute that is measured, disclosure measure design influences results.
\end{abstract}

KEY WORDS Disclosure indices; Disclosure determinants; Forward-looking information; Disclosure theories.

RESUMEN En la literatura sobre divulgación de información se han desarrollado diversas teorías para explicar los motivos que llevan a las empresas a divulgar más información. La evidencia empírica no apoya consistentemente las teorías y los resultados encontrados son contradictorios. Estas divergencias podrían estar ocasionadas por problemas implícitos a la medición de la información voluntaria. En este trabajo, se estudian dos cuestiones clave relacionadas con este problema. Primeramente, investigamos si el uso de índices de revelación que captan diferentes atributos informativos determina la validez de las teorías enunciadas sobre la divulgación de información. Por otro lado, analizamos la influencia de utilizar distintas medidas de la información. Los resultados muestran que los determinantes de atributos informativos más específicos son distintos de aquellos factores que influyen en la divulgación de atributos menos específicos. Además, independientemente del atributo informativo que es medido, el diseño de un índice de revelación influye en los resultados obtenidos.

PALABRAS CLAVE Divulgación de información; Determinantes de la divulgación; Información previsional; Teorías sobre divulgación.

\footnotetext{
* Acknowledgements: The authors are grateful for the valuable comments and suggestions made by the anonymous referees in the preparation of this article. The authors also want to thank Emma García-Meca and Juan Manuel García Lara for their discussions on previous versions of this paper.

** Corresponding author: Francisco Bravo Urquiza. Departamento de Contabilidad y Economía Financiera. Universidad de Sevilla. Avenida Ramón y Cajal, 1, 48018 Sevilla (Spain). Tel.: (+34) 954556067. Fax: (+34) 954557569. E-mail: pacobravo@ us.es
} 


\section{INTRODUCTION}

Various theories have been developed in the disclosure literature to explain the reasons behind the decision to disclose more and/or better information. Empirical tests of disclosure theories identify which characteristics of the companies determine disclosure (Singhvi and Desai, 1971; Firth, 1979; Cooke, 1992; Raffournier, 1995; Giner, 1997; Archambault and Archambault, 2003; Prencipe, 2004). Although the methodologies applied are similar, not only do the results lack consistency in their support of disclosure theories but they are also often contradictory (Ahmed and Courtis, 1999; Chavent et al., 2006). One possible explanation for these contradictory results lies in the difficulty inherent to the measurement of information disclosure. The difficulty in measuring voluntary disclosure is one of the most important problems encountered by empirical researchers in disclosure studies (Healy and Palepu, 2001). In this paper, we tackle this problem by investigating two key questions related to disclosure measurement. To the best of our knowledge, these questions remain unchallenged in the literature on disclosure determinants.

First, we aim to empirically test which determinants are related to which specific information attributes. In other words, we want to test how using disclosure indices that measure different information attributes affect the significance of some of the determinants proposed by disclosure theories. With this purpose in mind, we compare results obtained when using various disclosure indices that measure different information attributes in a regression analysis of disclosure determinants. The information attributes considered are quantity, coverage and quality.

Second, we study how disclosure index design influences the results of empirical analysis of disclosure theories. To this end, we compare two disclosure indices that capture the same information attribute, but which are designed in a different way.

Our empirical analysis is conducted on a sample of listed Spanish companies and focuses on the disclosure of forward-looking information. We find that size is the only determinant that significantly affects all the disclosure attributes considered. The significance of other determinants depends on the attributes of disclosure which are measured by the specific index adopted. Moreover, we will show that, even when we focus on a specific attribute of disclosure, the design of the index used for the measurement of that attribute affects the results of the analysis.

Disclosure theories do not generally provide an exhaustive definition of the term «disclosure». Theories assume that, under specific circumstances, companies disclose more information because perceived expected benefits exceed costs. However, the theoretical arguments are enunciated in a generic way and fail to explicitly define what exactly is meant by «more information» or «an increase in disclosure». Disclosure is a multidimensional concept that integrates various attributes (Beattie et al., 2004). Consequently, it is expected that the determinants of disclosure of specific information attributes will be different to those of other attributes. For instance, the factors that influence disclosure quantity can differ from the determinants of information quality. We test whether the use of disclosure measures that capture different information attributes results in empirical evidence showing that the 
disclosure determinants also differ. Disclosure indices that capture dissimilar information attributes — such as quantity, coverage or quality - coexist in the literature (Entwistle, 1999; Hussainey et al., 2003; Wallace et al., 1994; Giner, 1997; Prencipe, 2004; Beretta and Bozzolan, 2005; Cerbioni and Parbonetti, 2007). We expect that the general theoretical arguments will be verified when less specific disclosure measures are used (e.g.: quantity or coverage). However, the theoretical predictions on disclosure determinants may lack full verification when more specific measures (such as information richness or depth) are employed. This being the case, then the implications for research on disclosure determinants are substantial. It would highlight the need to enunciate theories on disclosure determinants more explicitly, by taking information attributes into consideration. In the same way, disclosure indices should be designed on the basis of specific information characteristics, in order to obtain empirical results of a more conclusive nature.

Disclosure index design is a complex task, affected by subjectivity. Several difficulties have to be faced when building a disclosure index, such as item selection and weighting (GarcíaMeca and Martínez, 2004). As Ahmed and Courtis (1999) suggest, the use of diverse disclosure measures is one possible explanation for the contradictory results found in empirical research on disclosure determinants. Self-constructed indices that capture coverage are the most commonly used measures. A common approach in this kind of study is to design an index that captures coverage of several informational items and to relate it to several company characteristics. Despite the controversial nature of this methodology, as far as we know there are no studies about the impact of different index designs on the results in this research area. Empirical evidence on this matter will highlight the need for the specific disclosure measure to be considered when interpreting results, and more importantly, when comparing these results with those in the prior literature.

This research contributes towards our understanding of the disclosure measurement and of the research on disclosure determinants. It sheds some light on the reasons why contradictory results on voluntary disclosure determinants have been documented. «Disclosure» as a concept is still not clearly defined in terms of specific information attributes. This lack of consensus on the disclosure index design may explain divergences in the results. The implications for future research include the necessity to be more precise about information attributes when developing theoretical hypotheses and the need to search for more clearly defined disclosure measures that provide comparable results.

This paper is organized as follows. The literature regarding disclosure theories and disclosure indices is reviewed in the next section. Section 3 describes data collection and the sample, whereas Section 4 explains the research method. Section 5 discusses the results of the empirical analysis and Section 6 summarizes the contributions of the paper.

\section{LITERATURE REVIEW}

Disclosure of financial information is an area that has triggered a great deal of academic interest in recent years. Among other topics, research is focused on the corporate characteristics that help to predict a firm's disclosure level. Even though similar methodologies and corporate characteristics have been used in the prior research on disclosure determinants, 
some disagreements have appeared in relation to some of these characteristics (Chavent et al., 2006). In some cases, results fail to support theoretical arguments; in others, results, from empirical studies that are designed in a similar fashion, differ (Cooke, 1989; Raffournier, 1995; Prencipe, 2004). These contradictory results suggest the existence of some open questions in this research area.

One of the most important drawbacks encountered by researchers has to do with the problems that are inherent to the measurement of voluntary disclosure (Healy and Palepu, 2001). We hypothesize that there are two main factors that might be causing these contradictory results: first, disclosure theories use a concept of disclosure that is not specifically defined in terms of information attributes; second, different disclosure measures are employed in each of the empirical studies. In this section, both the literature about disclosure theories and the literature on disclosure measure design are reviewed.

\subsection{VOLUNTARY DISCLOSURE THEORIES}

The determinants of voluntary disclosure have been subjected to major analysis. Several theories explain the reasons for companies to reveal voluntary information (under the assumption that firms perceive benefits from disclosure), including agency theory, signalling theory and political process theory, among others. Proprietary costs as well as costs derived from the collection and preparation of information must also be considered from a theoretical perspective (Prencipe, 2004). To a lesser extent, other types of costs have been found as limitations to the disclosure of information, such as corporate governance and monitoring, capital needs, litigation costs, and audit firm reputation (Ahmed and Courtis, 1999). The theoretical arguments on the determinants of voluntary information disclosure are summarized below.

Agency theory defines an agency relationship as a contract under which one or more persons (principals) engage another person (agent) to perform some service on their behalf which involves delegating some decision-making authority to the agent (Jensen and Meckling, 1976). It is expected that the agent will not always act in the best interest of the principal. Agency theory claims that conflicts are expected to arise when there is incomplete and asymmetric information between principal and agent in a company. Both parties may have different interests and this problem could be minimized by providing more information. Some determinants of voluntary information that have been commonly associated to the agency problem are size, leverage, profitability and listing status.

First, given that larger firms carry out a greater number of contracts which are more complex than smaller firms, agency costs depend on company size (Rodríguez Perez, 2004). Larger firms are expected to reveal more voluntary information to reduce these costs. Second, agency costs are higher when the proportion of debt increases. Agency theory predicts that a highly leveraged company has more of an obligation to satisfy the information needs of long-term and short-term creditors, and hence it may provide more detail to meet those needs than would a less leveraged firm (García-Meca et al., 2005). Third, higher margin and higher profitability lead to a greater level of disclosure in order to ob- 
tain and justify better contractual conditions. Managers will disclose detailed information to improve their compensation arrangements (Giner, 1997). Finally, listed companies are expected to provide more information due to the higher information requirements they face, or due to agency costs (Giner, 1995). Specifically, international listing status is also expected to influence disclosure. Disclosure serves to control the agency costs that appear when ownership is more disperse (García-Meca et al., 2005).

Signalling theory indicates that asymmetric information between a company and the investors causes adverse selection. To avoid this situation, companies disclose information voluntarily, providing signals to the market (Watts and Zimmerman, 1986). Size, profitability and growth are factors that influence the decision to disclose voluntary information to avoid adverse selection.

Information asymmetries will be larger for big companies, which justify more disclosure for mitigation purposes (Rodríguez Pérez, 2004). Moreover, firms with a high profitability will have a higher tendency to disclose more information to the markets, to increase investor confidence (Singhvi and Desai, 1971) and prevent undervaluation of their shares (Giner, 1997). Finally, growth and disclosure are expected to be positively related (Lev and Penman, 1990) since companies with high growth rates provide more information to be more attractive in the market.

Political process theory suggests that regulators make decisions based on the information disclosed by firms (Watts and Zimmerman, 1986). Companies disclose voluntary information to minimize these political costs. Size and profitability are incentives for companies to reveal more information to reduce these costs. Larger firms are subject to higher political costs, leading to a greater level of disclosure (Watts and Zimmerman, 1986). Higher information disclosure is expected to justify a firm's large profits and thus avoid legal obligations (Lang and Lundholm, 1993) and as a justification of the company's profit level (Giner, 1997). Political costs and the competitive environment also influence the level of information disclosed in an industry (Mora and Rees, 1996).

In addition, proprietary costs are considered as one of the most important limitations to information disclosure. Competitive disadvantages influence the decision to provide private information. Smaller firms are sensitive, to a great extent, to the disadvantages that, in terms of competitive edge, are derived from a higher disclosure level (Singhvi and Desai, 1971; Giner, 1995). The previous literature has also considered the costs derived from the collection and preparation of information as an obstacle to revealing more voluntary information. Company size plays an important role to minimize these costs, which decrease for larger firms (Land and Lundholm, 1993).

In summary, under the framework of these theories, the prior research has employed variables, such as size, leverage, profitability, growth and listing status as determinants of voluntary information disclosure. However, theories refer to information disclosure in general terms, while this concept embodies several attributes or dimensions. The reasons to increase or improve the disclosure of a specific information attribute might be different to the rationale for enhancing another attribute. Disclosure indices that capture different information attributes concur in the literature. Our objective is to test whether the deter- 
minants of a specific information attribute disclosure differ from those of other attributes. This being the case, existing disclosure theories will not remain applicable in all cases.

\subsection{Measurement of Disclosure}

Disclosure is measured in the prior research by following various approaches, all under the implicit assumption that disclosure quality is what is being measured (Beattie et al., 2004). One approach is the use of scores provided by analysts according to the amount of information disclosed-such as scores elaborated by the Association for Investment Management and Research [AIMR ${ }^{(1)}$ ], and Standard \& Poor's (S\&P). However, it has been argued that they are biased owing to analysts' subjectivity or the number of companies that compose the AIMR or S\&P samples (Healy and Palepu, 2001). Another approach is the use of self-constructed indices. This approach is the most frequently employed due to the need for disclosure measures that are valid regardless of the companies selected or the kind of information analysed.

Self-constructed indices commonly measure voluntary information in general (Chow and Wong-Boren, 1987; Raffournier, 1995; Botosan, 1997; Depoers, 2000), or mandatory information (Wallace and Naser, 1995, Chen and Jaggi, 2000). However, some studies have employed disclosure indices to measure specific information, like intellectual capital (Cerbioni and Parbonetti, 2007; Li et al., 2008), environmental and social (Williams, 1999) or forward-looking information (Beretta and Bozzolan, 2005; Aljifri and Hussainey, 2007).

As mentioned in previous sections, diverse information attributes are considered when designing self-constructed measures. Some disclosure indices are based on information quantity (Entwistle, 1999; Williams, 1999; Hussainey et al., 2003; Aljifri and Hussainey, 2007; Li et al., 2008). Measures of a more specific and complex nature have recently been developed, including several dimensions related to information richness (Beretta and Bozzolan, 2005; Cerbioni and Parbonetti, 2007).

Nevertheless, the majority of studies employ indices that capture coverage of several information categories. Although most of disclosure indices do not assign any weight to the information items (Chow and Wong-Boren, 1987; Cooke, 1989; Raffournier, 1995; Giner, 1997; Depoers, 2000), some of them select weighted items (Singhvi and Desai, 1971; Buzby, 1975; Chow and Wong-Boren, 1987). Several indices have also considered information specificity to obtain a proxy for information scope by assigning a higher value to quantitative information (Botosan, 1997; Robb et al., 2001).

Despite the proliferation of information indices of similar design, the results from research on disclosure determinants are contradictory. Most of the studies agree on the existence of a positive relationship between size and disclosure, indicating that larger companies disclose more information (Buzby, 1975; Firth, 1979; McNally et al., 1982; Cooke, 1989; Wallace et al., 1994; Giner, 1997; Depoers, 2000; Alsaeed, 2005). However, other studies show no evidence on this relationship (Malone et al., 1993; Ahmed, 1996, Prencipe, 2004). Disagreements are also found in studies on forward-looking information; some research finds a

(1) As of 9 May 2004, AIMR changed its name to CFA institute. 
significant relationship (Kent and Ung, 2003; Hossain et al., 2005), whereas other studies do not support this result (García and Monterrey, 1993; Aljifri and Hussainey, 2007).

Other widely studied factors, such as profitability, leverage, auditor or industry, show more contradictory results. There is no consensus in previous research on how profitability influences disclosure. Giner (1997) documents a positive relationship, while some others do not (McNally et al., 1982; Raffournier, 1995; Prencipe, 2004). A negative association between profitability and disclosure level has also been documented (Wallace et al., 1994). Research on forward-looking information disclosure also shows mixed results (Hossain et al., 2005; Aljifri and Hussainey, 2007).

The results from research on leverage and disclosure are also confusing: some authors find a significant relationship (Mora and Rees, 1996), others find no evidence (Chow and WongBoren, 1987; Wallace et al., 1994; Raffournier, 1995, among others). Studies on forwardlooking information disclosure find both a significant relationship (Aljifri and Hussainey, 2007) and no evidence about this variable (Kent and Ung, 2003). Some research finds a positive relationship between auditor firm and disclosure (Ahmed, 1996; Giner, 1997). Nevertheless, empirical evidence is mixed, since other findings support no such positive relationship (Firth, 1979; McNally et al., 1982; Wallace et al., 1994). Regarding industry, whereas some studies show a positive relationship between industry and voluntary disclosure (Cooke, 1992), others do not (McNally et al., 1982; Meek et al., 1995). Mixed results are also found in forward-looking information studies (García and Monterrey, 1993; Aljifri and Hussainey, 2007).

Above all, a major difficulty faced by researchers in this area is the measurement of disclosure. Although all diverse information attributes should be taken into account to make up a comprehensive disclosure measure, existing disclosure indices generally concentrate on coverage. Moreover, there are no general guidelines for the design of an index, which is usually constructed by the researchers themselves to meet specific research needs. As pointed out earlier, the results of prior research are contradictory and hardly comparable. In an attempt to offer some explanation, we study the use of disclosure indices that are designed to capture similar information attributes and their effects on empirical results.

\section{SAMPLE SELECTION}

The sample is composed of the listed companies that make up the Spanish IBEX 35 stock market index during the period 2000-2004. Listed and larger firms are more likely to provide voluntary information, which benefits further analysis. For a company to be included in the sample, it had to be one of the companies appearing in the index in at least one of those years. Over that period, 36 companies belonged at least once to the set of companies that make up the stock market index. We excluded financial companies due to the fact that their special characteristics could bias the results. The information was gathered for the years: 2002, 2003 and 2004. The final sample included 36 companies; therefore there are 108 firm-year observations. 


\section{RESEARCH METHOD}

We test whether the theories on disclosure determinants are applicable when specific information attributes are considered. Several disclosure measures capturing different information attributes are compared in an empirical investigation of voluntary disclosure determinants. The factors causing disclosure in terms of a specific information attribute may differ from the reasons that determine another attribute. To this end, we compare disclosure indices that measure information quantity, coverage and quality. In addition, we compare two disclosure indices that capture coverage - but which are designed differently - to study if the disclosure measure design determines the results obtained.

The information disclosed by companies was coded according to specific criteria that had been previously established when designing the indices (see Section 4.1.). The sources of information examined were the annual reports. Previous research indicates that annual reports provide a good proxy for the level of information disclosed by a company (Botosan, 1997) and that the information contained in annual reports is positively correlated with the information provided in other sources (Land and Lundholm, 1993). The code unit chosen was the sentence, since using sentences for both coding and measurement seems likely to provide complete, reliable and meaningful data for further analysis (Milne and Adler, 1999).

The information analysed was the forward-looking information disclosed in the annual report. We focused on only one kind of information since otherwise, coding every sentence in each of the annual reports in the sample would imply an endless task. Forward-looking information was chosen due to its relevance for external users. As Kieso and Weygant (1986) indicate, forward-looking information disclosure is beneficial for several reasons: since historical information is insufficient for appropriate decision making, then information risk would reduce, thereby improving investment decisions and future cash-flows estimation. Moreover, forward-looking information is included in most of the corporate disclosure frameworks. The usefulness of forward-looking financial information for investors has been pointed out in several reports such as the Trueblood Report (AICPA, 1973) and the Corporate Report (ICAEW, 1975), and more recently by the FASB (2001) report titled Improving Business Reporting: Insights into Enhancing Voluntary Disclosure, and by the ICAEW (2002) report titled Prospective Financial Information: Guidance for UK Directors, and by the CICA (2002) report titled Management's discussion and analysis; Guidance on preparation and disclosure. Finally, we decided to analyze forward-looking information thanks to the availability of a more complex measure that captures different dimensions specifically related to forward-looking information disclosure quality (designed by Beretta and Bozzolan, 2005).

The coding process started with the execution of a preliminary test so as to set up several coding rules. Two annual reports (excluded from the sample) were examined independently by two different researchers, with the purpose of identifying possible disagreements and of measuring reliability. The whole sample (108 annual reports) was then coded according to the criteria established when designing each index. At the end of the process, a reliability test was performed by employing the alpha agreement coefficient proposed by Krippendorf (1980). Once the whole sample was coded and the robustness of this process was verified, an empirical analysis was performed through a regression analysis which examined forward-looking information determinants. 


\subsection{DeSIGN OF THE INDICES}

We compare several indices that capture different information attributes. Disclosure determinants may differ depending on the information attribute that is being considered. Traditional disclosure theories are satisfied when the term «higher disclosure» is defined in general terms, but might not be satisfied if more complex information attributes are considered. Theories are expected to be satisfied when measuring information quantity. However, companies perceive higher costs when providing more specific information, and the determinants of attributes related to information richness might not agree with existing disclosure theories.

To this end, we use three indices that differ on the specificity of the information attributes captured (from simpler to more complex and detailed). First, we chose a simple index that captures information quantity (quantity index). Second, given that most of the indices employed in the prior literature capture informational coverage, we designed an index (scope index) that reflects coverage of specific topics. Third, we include in the analysis the multidimensional index proposed by Beretta and Bozzolan (2005) ${ }^{(2)}$, which is claimed to be a proxy for disclosure quality (named quality index). Moreover, each of the dimensions that make up the quality index is also considered in the analysis. In addition, we suggest that the previous contradictory results from research on disclosure determinants might be caused by the use of different disclosure measures. To evaluate this claim, we compare two indices that are similar in design; the scope index and the coverage dimension of the quality index.

The coding process required the analysis of 108 annual reports in order to find sentences with forward-looking information. These sentences were coded according to the criteria mentioned below for each index.

\subsubsection{Quantity index}

The quantity index (QNI) measures the amount of information by taking into account the number of sentences with forward-looking information. Its purpose is to capture disclosure quantity - which is standardised in order to make it relative to the sample- in accordance with the following formula:

$$
Q N I_{i}=\left(f l_{i}-\min \right) /(\operatorname{Max}-\min )
$$

Where:

$f l_{i}$ : is number of sentences with forward-looking information disclosed by company $i$.

Max: is maximum number of sentences with forward-looking information disclosed by a company across the sample.

min: is minimum number of sentences with forward-looking information disclosed by a company across the sample.

The quantity index ranges between 0 and 1.

(2) Beretta and Bozolan (2005) quality index robustness has been assessed by different methods in order to support its validity to capture disclosure quality. An updated version of the working paper (Beretta and Bozolan, 2005) has been published recently (Beretta and Bozzolan, 2008; Beretta et al., 2009). 


\subsubsection{Scope index}

The scope index (SCI) is a self-constructed index similar to many indices employed in the previous literature. Considering a given a list of items, the value of the index for a particular company is obtained by dividing the number of information items disclosed by that company by the total number of information disclosure items that might be disclosed. This index is composed of forward-looking information items which were selected by taking into account the guidance offered by professional bodies and the classification scheme suggested by Robb et al. (2001). We propose the following six categories of forward-looking information: environment (1), evolution (2), goals, strategies and business policies (3), information related to dividends policy (4), information about future investments (5), organization and corporate structure (6).

A higher value is assigned to quantitative information (as in Botosan, 1997, among others). Quantitative information is more specific and seems to imply a greater responsibility, and hence an increase in reputational costs (Bhojraj, 1999). Furthermore, narrative information is more easily manipulated (Balata and Breton, 2005). The categories are not weighted, but the score of each item ranges from 0 points if there is no forward-looking information of that type, 0.5 points if the information provided is narrative and 1 point if the information is quantitative.

\subsubsection{Quality index}

The quality index is designed according to Beretta and Bozzolan (2005) and is claimed to capture quality of forward-looking information disclosed by companies. Although quality is an abstract concept and its measurement is complex, according to some authors (Beattie et al., 2004; Beretta and Bozzolan, 2005) it is possible to obtain a proxy for disclosure quality which appreciates different dimensions of measurement.

The quality index distinguishes between two dimensions that are measured by two different indices: the relative quantity index $(R Q T)$ and the richness index $(R C N)^{(3)}$. The final value of the quality index (QLI) is obtained by taking the mean value of the two indices.

$$
Q L I=\frac{1}{2}\left(R Q T_{i}+R C N_{i}\right)
$$

The relative quantity index (RQT) is calculated as the difference between observed disclosure for a company and estimated disclosure (estimated through standardized residuals of an $O L S$ regression, using size and industry as independent variables). The richness index $(R C N)$ is designed to capture disclosure quality, and is calculated by averaging two new dimensions associated to information richness: width (WID) and depth (DEP).

$$
R C N_{i}=\frac{1}{2}\left(W I D_{i}+D E P_{i}\right)
$$

(3) The design of this index is explained in detail in Beretta and Bozzolan (2005 \& 2008). 
Width (WID) depends on both coverage (COV) of important topics and on disclosure dispersion (DIS) (which measures the concentration of the items disclosed). The value of the width index (WID) is obtained as the arithmetic mean of the coverage and dispersion dimensions.

$$
W I D_{i}=\frac{1}{2}\left(C O V_{i}+D I S_{i}\right)
$$

Coverage (COV) is calculated by dividing the topics disclosed at least once into the total number of topics considered, and dispersion (DIS) corresponds to the standardized Entropy index (Beretta and Bozzolan, 2008). Forward-looking information disclosure is classified by taking suggestions from the Jenkins report (AICPA, 1994) into account, and the following items are then chosen: strategy (1), corporate background, including financial structure (2), corporate structure (3), organizational structure (4) and operations (5), and external environment, including political, economic, financial and social items (6), environmental topics (7), industry (8) and legal aspects (9).

$$
\begin{gathered}
C O V_{i}=\frac{1}{s t} \sum_{j=1}^{s t} I N F_{i j} \\
D I S_{i}=\frac{-\sum_{j=1}^{s t} p_{i j} 1 n p_{i j}}{1 n s t}
\end{gathered}
$$

Where:

$I N F_{i j}$ : has a value of 1 if the annual report of company $i$ discloses forward-looking information about subtopic $j$, and is 0 otherwise.

st: is the number of topics ( 9 topics).

pij: is the amount of information disclosed in subtopic $j$ (number of sentences) divided by

the total disclosure of company $i$ (the total number of sentences with forward-looking information).

The coverage dimension is built in a similar way to most of the indices used in the prior literature. Although this dimension looks quite similar to the scope index (SCI), they differ in the selection of categories, as well as in the treatment of quantitative information. For this reason, this measure was compared to the scope index to evaluate the influence that the use of different disclosure measures has on the results from research on disclosure determinants.

Depth (DEP) depends on the type of measure used in an information unit, on the communication of the economic sign of the disclosed items and on the information profile. Depth is obtained averaging the economic sign and measure (ESM) and outlook profile (OTL) indices.

$$
D E P_{i}=\frac{1}{2}\left(E S M_{i}+O T L_{i}\right)
$$


The type of measure is captured by the MSR index, which is defined as the ratio between the number of phrases (forward-looking) containing a measure, and the total number of pieces of forward-looking information considered in the annual report. The expected impact on future performance is measured by the economic sign index (ES), which counts the number of pieces of forward-looking information disclosed that contain an indication of the sign of effective or expected impact on actual or future performance of the item disclosed. This number is then calculated as the proportion of the total number of phrases (forwardlooking) considered in the annual report. The ESM index is calculated by aggregating the $M S R$ and $E S$ sub-indices.

$$
E S M_{i}=\frac{1}{2}\left(M S R_{i}+E S_{i}\right)
$$

The outlook profile (OTL) attribute is calculated by aggregating two other dimensions. Information nature is captured by the $A C P$ index, which is calculated by dividing the number of sentences with forward-looking information on decisions, programs, and actions into the total number of sentences with forward-looking information. Information relevance is captured by the $F L$ index, which considers sentences with forward-looking information that include information useful in the generation of earnings forecasts $(F L)$.

$$
O T L_{i}=\frac{1}{2}\left(A C P_{i}+F L_{i}\right)
$$

Consequently, the quality index is composed of several dimensions that are expected to be related to information quality.

\subsection{EMPIRICAL ANALYSIS}

We study the corporate characteristics that explain the decision of a company to disclose forward-looking information, by following previous disclosure research and in particular, by taking into account prior studies on forward-looking information disclosure as a reference point. A regression analysis is undertaken through an equation that relates each disclosure index (dependent variable) to several explanatory variables (independent variables). Along the lines of previous studies, size, proprietary costs, profitability, leverage, growth and foreign exchange listing are selected as corporate characteristics that may explain company incentives to disclose. Our aim is not to cover every factor considered in the prior literature, but to include in the model those factors that are most commonly associated to disclosure theories. The definition of the explanatory variables is the following:

- Size (SIZE): In spite of having been measured by different magnitudes (e.g.: total assets, operating revenues or market value), most of the studies find that this variable is significantly and positively associated with disclosure. As a proxy for size we use operating revenues.

- Profitability (ROE): Several variables have been employed in the previous literature to measure profitability. In this research, we select return on equity (ROE).

- Leverage (LEV): Leverage is calculated by dividing total debt by total assets.

- Growth (OR_GROWTH): Growth in operating revenues is used as a proxy for growth.

- Foreign exchange listing (FE_LISTING): Due to the fact that most of the companies in the sample were listed in more than one foreign stock market, a dummy variable was 
created with a value of 1 if the company was listed in the New York Stock Exchange and/or the London Stock Exchange, and 0 otherwise.

The general model used is:

$$
D I_{i}=\alpha+\beta_{1} S_{I Z E_{i}}+\beta_{2} R O E_{i}+\beta_{3} L E V_{i}+\beta_{4} O R_{-} G R O W T H_{i}+\beta_{5} F_{-} L I S T I N G_{i}+\varepsilon
$$

where $D I_{i}$ refers to forward-looking information disclosure, which is measured through the different indices (quality, scope, and quantity). The dimensions of the Quality index are also considered as disclosure measures. Attention is paid to some specific information attributes, such as coverage (designed is the same way as the disclosure indices that are employed in the previous literature) and the depth dimensions (which are directly related to information richness).

Since the dependent variable is measured through different indices, several regression models are estimated. A multivariate analysis is performed, where 36 firms -in years 2002, 2003 and 2004 - are studied, which provides a panel data of 108 firm-year observations. The models are estimated for pooled data for three years (2002-2004) using intercept dummies for individual years to capture fixed effects (Greene, 1997: 621) thereby minimizing temporal effects. The results of each model are compared and their significance analyzed.

\section{RESULTS AND DISCUSSION}

Descriptive statistics for disclosure indices and explanatory variables are shown in Table 1 . There are some differences in the values of the disclosure indices. The quality index (QLI) mean value is 0.47 . On average, companies in the sample cover $64 \%$ and $55 \%$ of the information items included in the scope (SCI) index and the coverage (COV) dimension, respectively. The lowest mean value is obtained by the quantity index (QNI), at just 0.23 . These divergences in descriptive statistics might give rise to differences when studying determinants of information disclosure. The values of the explanatory variables present a high dispersion. However, there are no outliers that influence further analysis.

TABLE 1

DESCRIPTIVE STATISTICS: DISCLOSURE INDICES AND EXPLANATORY VARIABLES (108 FIRM-YEAR OBSERVATIONS. YeARS 2002, 2003 \& 2004)

\begin{tabular}{|l|c|c|c|c|}
\hline \multicolumn{1}{|c|}{ Variables $^{a}$} & Mean & Standard Deviation & Minimum & Maximum \\
\hline Quantity index & 0.23 & 0.19 & 0.00 & 1.00 \\
\hline Scope index & 0.64 & 0.16 & 0.33 & 1.00 \\
\hline Quality index & 0.47 & 0.10 & 0.24 & 0.83 \\
\hline Coverage dimension & 0.55 & 0.14 & 0.22 & 0.89 \\
\hline SIZE & $7,343.97$ & $9,358.41$ & 114.15 & 41,406 \\
\hline ROE & 14.16 & 32.17 & -249.22 & 74.41 \\
\hline LEV & 73.47 & 16.51 & 20.25 & 97.00 \\
\hline
\end{tabular}


TABLE 1 (cont.)

DESCRIPTIVE STATISTICS: DISCLOSURE INDICES AND EXPLANATORY VARIABLES (108 FIRM-YEAR OBSERVATIONS. YEARS 2002, 2003 \& 2004)

\begin{tabular}{|l|c|c|c|c|}
\hline \multicolumn{1}{|c|}{ Variables $^{a}$} & Mean & Standard Deviation & Minimum & Maximum \\
\hline OR_GROWTH & 13.76 & 57.07 & -45.99 & 514.34 \\
\hline FE_LISTING & 0.17 & 0.38 & 0.00 & 1.00 \\
\hline
\end{tabular}

a The quantity index measures information amount taking into account the number of sentences with forward-looking information. The scope index is obtained by dividing the number of information items disclosed by a company by the total number of information disclosure items that might be disclosed (six forward-looking information items: environment (1), evolution (2), goals, strategies and business policies (3), information related to dividends policy (4), information about future investments (5), organization and corporate structure (6)). The quality index (Beretta and Bozzolan, 2005) is an aggregated index composed of two dimensions, relative quantity and richness. The relative quantity index (RQT) is calculated as the difference between observed disclosure for a company and estimated disclosure. The richness index (RCN) is designed to capture disclosure quality, and is calculated by averaging two new dimensions associated to information richness: width (WID) and depth (DEP). Width (WID) depends on both coverage (COV) of important topics and on disclosure dispersion (DIS) (which measures concentration of items disclosed). Depth (DEP) depends on the type of measure used in an information unit, on the communication of the economic sign of the disclosed items and on information profile.

$S I Z E$ is defined as operating revenues; $R O E$ is return on equity; $L E V$ is calculated dividing total debt between total assets; $O R$ GROWTH is growth in operating revenues; FE_LISTING is a dummy variable with a value of 1 if the company is listed in the New York Stock Exchange or the London Stock Exchange, and 0 otherwise. Operating revenues are in millions of euros.

As an initial approach, Pearson correlations were calculated. Results are shown in Table 2 and reveal the relationships between the disclosure indices and the explanatory variables included in the statistical model. The quantity index is correlated with all explanatory variables apart from ROE. Size is the variable that shows the highest correlation with the three disclosure indices and the coverage dimension. Nevertheless, there is no evidence of autocorrelation problems since the coefficients are low and not significant in many of the cases.

The regression model was then estimated by capturing fixed effects (Greene, 1997). Table 3 contains results from the estimation of the model with four different dependent variables: the three disclosure indices (quality, scope and quantity) and the coverage dimension of the quality index. Table 4 shows the results obtained when the dimensions that compose the quality index are used as dependent variables. Application of the Belsley test (Belsley et al., 1980) revealed no problem of multicollinearity. Similarly, White's test (White, 1980) proved that the homocedasticity assumption was not violated. Finally, the Durbin and Watson test confirmed that there was no autocorrelation (Durbin and Watson, 1950). The F-statistic shows the power of the independent variables to explain variation in the dependent variable. Since in most cases the significance value of the F-statistic is small (lower than 0.05), we can state that independent variables do a good job in explaining variation in the dependent variable.

Disclosure theories use the concept of disclosure in a generic way, as they usually predict that companies will increase the level of disclosure or have a better disclosure under existence of particular company conditions. However, theories usually fail to prescribe which specific information attributes will improve or what should be considered as better disclosure. Therefore disclosure theories may not always be valid since disclosure behaviour of companies will vary depending on the information attribute considered. Some of the hypotheses of disclosure theories will be verified when information disclosure is measured with an index defined in generic terms (such as quantity), but other different hypotheses will be verified when the index captures information attributes of a more complex and detailed nature (such as information depth). 


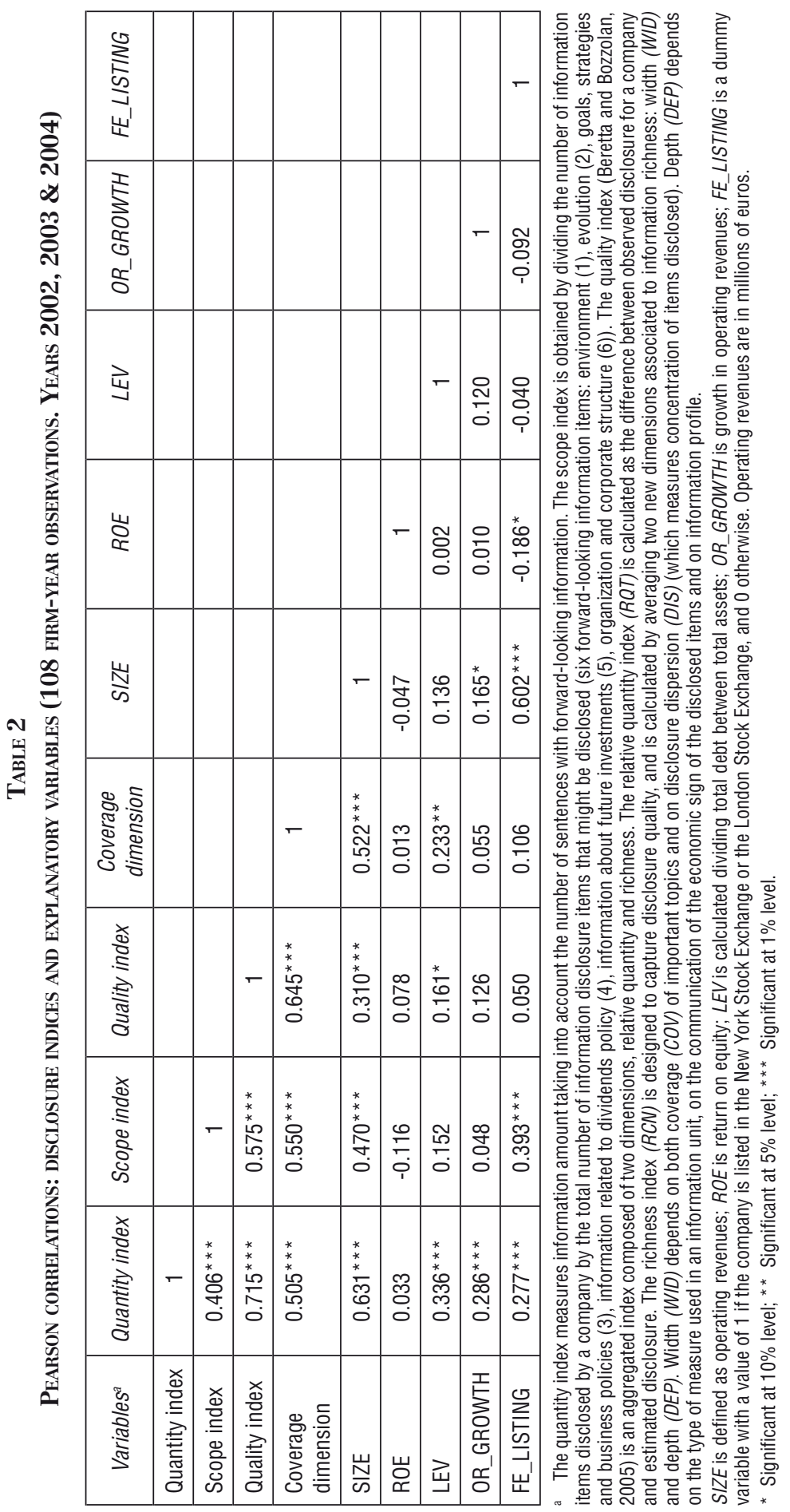


TABle 3

Multivariate LINEAR REGRESSIONS (FiXed EFFECTS MODEL)

(108 firm-year observations. Years 2002, $2003 \& 2004, t$-statistics in parentheses)

$$
D I_{i}=\alpha+\beta_{1} S I Z E_{i}+\beta_{2} R O E_{i}+\beta_{3} L E V_{i}+\beta_{4} \text { OR_GROWTH }_{i}+\beta_{5} \text { FE LISTING }_{i}+\varepsilon
$$

\begin{tabular}{|c|c|c|c|c|}
\hline \multicolumn{5}{|c|}{ DependeNT VARIABLEA: DISCLOSURE INDEX (DI) } \\
\hline $\begin{array}{c}\text { Explanatory } \\
\text { Variables }^{b}\end{array}$ & Quantity index & Scope index & Quality index & Coverage dimension \\
\hline Intercep $_{t}$ & $\begin{array}{c}-0.011 \\
(-0.206)\end{array}$ & 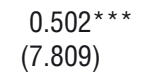 & $\begin{array}{l}0.407^{\star * *} \\
(9.858)\end{array}$ & $\begin{array}{l}0.401^{\star \star \star} \\
(7.680)\end{array}$ \\
\hline SIZE & $\begin{array}{l}0.672^{\star \star *} \\
(7.377)\end{array}$ & $\begin{array}{l}0.347^{\star \star * *} \\
(3.037)\end{array}$ & $\begin{array}{l}0.386^{\star * *} \\
(3.153)\end{array}$ & $\begin{array}{l}0.581^{\star * *} \\
(5.315)\end{array}$ \\
\hline$R O E$ & $\begin{array}{c}0.014 \\
(0.197) \\
\end{array}$ & $\begin{array}{c}-0.075 \\
(-0.852) \\
\end{array}$ & $\begin{array}{c}0.043 \\
(0.459) \\
\end{array}$ & $\begin{array}{c}0.019 \\
(0.231) \\
\end{array}$ \\
\hline LEV & $\begin{array}{l}0.226^{\star * *} \\
(3.188)\end{array}$ & $\begin{array}{c}0.117 \\
(1.325)\end{array}$ & $\begin{array}{c}0.108 \\
(1.146)\end{array}$ & $\begin{array}{c}0.158^{*} \\
(1.873)\end{array}$ \\
\hline OR_GROWTH & $\begin{array}{l}0.166^{\star *} \\
(2.295)\end{array}$ & $\begin{array}{c}-0.009 \\
(-0.105)\end{array}$ & $\begin{array}{c}0.038 \\
(0.395)\end{array}$ & $\begin{array}{c}-0.070 \\
(-0.814)\end{array}$ \\
\hline FE_LISTING & $\begin{array}{c}-0.160^{*} \\
(-1.756)\end{array}$ & $\begin{array}{c}0.174 \\
(0.904)\end{array}$ & $\begin{array}{c}-0.166 \\
(-1.364) \\
\end{array}$ & $\begin{array}{c}-0.113 \\
(-1.035) \\
\end{array}$ \\
\hline Adjusted $R^{2}$ & 0.499 & 0.216 & 0.100 & 0.276 \\
\hline$F(p$-value $)$ & $\begin{array}{l}16.082 \\
(0.000)\end{array}$ & $\begin{array}{c}5.200 \\
(0.000)\end{array}$ & $\begin{array}{c}2.074 \\
(0.013)\end{array}$ & $\begin{array}{c}9.172 \\
(0.000)\end{array}$ \\
\hline
\end{tabular}

a The quantity index measures information amount taking into account the number of sentences with forward-looking information. The scope index is obtained by dividing the number of information items disclosed by a company by the total number of information disclosure items that might be disclosed [six forward-looking information items: environment (1), evolution (2), goals, strategies and business policies (3), information related to dividends policy (4), information about future investments (5), organization and corporate structure (6)]. The quality index (Beretta and Bozzolan, 2005) is an aggregated index composed of two dimensions, relative quantity and richness. The relative quantity index $(R Q T)$ is calculated as the difference between observed disclosure for a company and estimated disclosure. The richness index $(R C N)$ is designed to capture disclosure quality, and is calculated by averaging two new dimensions associated to information richness: width (WID) and depth (DEP). Width (WID) depends on both coverage (COV) of important topics and on disclosure dispersion (DIS) (which measures concentration of items disclosed). Depth (DEP) depends on the type of measure used in an information unit, on the communication of the economic sign of the disclosed items and on information profile.

${ }_{b}$ SIZE is defined as operating revenues; $R O E$ is return on equity; $L E V$ is calculated dividing total debt between total assets; $O R$ GROWTH is growth in operating revenues; FE_LISTING is a dummy variable with a value of 1 if the company is listed in the New York Stock Exchange or the London Stock Exchange, and 0 otherwise. Operating revenues are in millions of euros.

* Significant at $10 \%$ level; ** Significant at $5 \%$ level; ${ }^{* * *}$ Significant at $1 \%$ level.

The quantity index was defined in general terms, simply by capturing information quantity. When using the quantity index (QNI), results in Table 3 indicate that size, leverage, and growth are positively related to forward-looking information disclosure, at $1 \%, 1 \%$ and $5 \%$, respectively. Similar to the evidence found in previous studies, this result supports the hypothesis, suggested by agency, signalling, and political process theories, that larger firms have incentives to reveal more voluntary information. It also corroborates the agency theory prediction that highly-leveraged companies will provide more information. Finally, significance of the growth variable confirms the signalling theory hypothesis that companies with high growth rates have incentives to increase disclosure to convey that information to the market. 


\section{TABLE 4}

MuLTIVARIATE LINEAR REGRESSIONS: QUALITY INDEX DIMENSIONS (FIXED EFFECTS MODEL) (108 firm-year observations. Years 2002, $2003 \& 2004, t$-statistics in parentheses)

$$
D I_{i}=\alpha+\beta_{1} S_{I Z E_{i}}+\beta_{2} R O E_{i}+\beta_{3} L E V_{i}+\beta_{4} O_{-} \text {GROWTH }_{i}+\beta_{5} \text { FE_LISTING }+\varepsilon
$$

\begin{tabular}{|c|c|c|c|c|c|c|}
\hline \multicolumn{7}{|c|}{ DEPENDENT VARIABLEa: DISCLOSURE INDEX (DI) } \\
\hline $\begin{array}{c}\text { Explanatory } \\
\text { Variables }^{b}\end{array}$ & $\begin{array}{c}\text { Coverage } \\
\text { (COV) }\end{array}$ & $\begin{array}{c}\text { Dispersion } \\
\text { (DIS) }\end{array}$ & Width (WID) & $\begin{array}{l}\text { Economic } \\
\text { Sign (ESM) }\end{array}$ & $\begin{array}{c}\text { Outlook } \\
\text { Profile (OTL) }\end{array}$ & Depth (DEP) \\
\hline Intercep $p_{t}$ & $\begin{array}{l}0.401^{* * *} \\
(7.680)\end{array}$ & $\begin{array}{l}0.481^{* * *} \\
(11.031)\end{array}$ & $\begin{array}{l}0.441^{* * *} \\
(9.946)\end{array}$ & $\begin{array}{l}0.581^{\star * *} \\
(8.289)\end{array}$ & $\begin{array}{l}0.790^{* * *} \\
(13.086)\end{array}$ & $\begin{array}{l}0.680^{* * *} \\
(12.704)\end{array}$ \\
\hline SIZE & $\begin{array}{l}0.581^{* * *} \\
(5.315)\end{array}$ & $\begin{array}{l}0.542^{* * *} \\
(4.710)\end{array}$ & $\begin{array}{l}0.605^{\star * *} \\
(5.449)\end{array}$ & $\begin{array}{c}0.006 \\
(0.050)\end{array}$ & $\begin{array}{c}-0.010 \\
(-0.083)\end{array}$ & $\begin{array}{c}-0.002 \\
(-0.014)\end{array}$ \\
\hline$R O E$ & $\begin{array}{c}0.019 \\
(0.231)\end{array}$ & $\begin{array}{c}0.132 \\
(1.488)\end{array}$ & $\begin{array}{l}0.074 \\
(0.871)\end{array}$ & $\begin{array}{c}0.125 \\
(1.265)\end{array}$ & $\begin{array}{c}0.095 \\
(1.016)\end{array}$ & $\begin{array}{c}0.134 \\
(1.394)\end{array}$ \\
\hline LEV & $\begin{array}{c}0.158^{*} \\
(1.873)\end{array}$ & $\begin{array}{c}0.107 \\
(1.206)\end{array}$ & $\begin{array}{c}0.145^{*} \\
(1.700)\end{array}$ & $\begin{array}{c}-0.020 \\
(-0.205)\end{array}$ & $\begin{array}{c}-0.127 \\
(-1.360)\end{array}$ & $\begin{array}{c}-0.079 \\
(-0.820)\end{array}$ \\
\hline OR_GROWTH & $\begin{array}{c}-0.070 \\
(-0.814)\end{array}$ & $\begin{array}{c}-0.073 \\
(-0.800)\end{array}$ & $\begin{array}{c}-0.076 \\
(-0.870)\end{array}$ & $\begin{array}{c}-0.125 \\
(-1.228)\end{array}$ & $\begin{array}{l}-0.310^{* * *} \\
(-3.243)\end{array}$ & $\begin{array}{l}-0.260^{\star *} \\
(-2.639)\end{array}$ \\
\hline FE_LISTING & $\begin{array}{c}-0.113 \\
(-1.035)\end{array}$ & $\begin{array}{l}-0.380^{* * *} \\
(-3.303)\end{array}$ & $\begin{array}{l}-0.248^{* *} \\
(-2.234)\end{array}$ & $\begin{array}{c}0.118 \\
(0.915)\end{array}$ & $\begin{array}{c}-0.140 \\
(-1.052)\end{array}$ & $\begin{array}{c}-0.004 \\
(-0.032)\end{array}$ \\
\hline Adjusted $R^{2}$ & 0.276 & 0.198 & 0.253 & -0.003 & 0.107 & 0.052 \\
\hline$F(p$-value $)$ & $\begin{array}{c}9.172 \\
(0.000)\end{array}$ & $\begin{array}{c}6.278 \\
(0.000)\end{array}$ & $\begin{array}{c}8.244 \\
(0.000)\end{array}$ & $\begin{array}{c}0.933 \\
(0.463)\end{array}$ & $\begin{array}{c}3.565 \\
(0.005)\end{array}$ & $\begin{array}{c}2.175 \\
(0.063)\end{array}$ \\
\hline
\end{tabular}

a The dependent variables in the different models are the dimensions that compose the quality index of Beretta and Bozzolan (2005). The quality index is an aggregated index composed of two dimensions, relative quantity and richness. The relative quantity index is calculated as the difference between observed disclosure for a company and estimated disclosure. The richness index (RCN) is designed to capture disclosure quality, and is calculated by averaging two new dimensions associated to information richness: width (WID) and depth (DEP). Width (WID) depends on both coverage (COV) of important topics and on disclosure dispersion (DIS) (which measures concentration of items disclosed). Depth (DEP) depends on the type of measure used in an information unit and on the communication of the economic sign of the disclosed items (EMS index) and on information profile (OTL). The ESM index is calculated by aggregating the MSR and ES sub-indices. The MSR index captures the type of measure, which is defined as the ratio between the number of phrases (forward-looking) containing a measure and the total number of pieces of forward-looking information considered in the annual report. The expected impact on future performance is measured by the economic sign index $(E S)$, which counts the number of pieces of forward-looking information disclosed containing an indication of the sign of effective or expected impact on actual or future performance of the item disclosed out of the total number of phrases (forward-looking) considered in the annual report. The outlook profile (OTL) attribute is calculated by aggregating two other dimensions. Information nature is captured by the $A C P$ index, which is calculated dividing the number of sentences with forward-looking information on decisions, programs, and actions into the total number of sentences with forward-looking information. Information relevance is captured by the $F L$ index, which considers sentences with forward looking information that include information useful to make earnings forecasts (FL).

b $S I Z E$ is defined as operating revenues; $R O E$ is return on equity; $L E V$ is calculated dividing total debt between total assets; $O R$ GROWTH is growth in operating revenues; FE_LISTING is a dummy variable with a value of 1 if the company is listed in the New York Stock Exchange or the London Stock Exchange, and 0 otherwise. Operating revenues are in millions of euros.

* Significant at 10\% level; ${ }^{* *}$ Significant at $5 \%$ level; ${ }^{* * *}$ Significant at $1 \%$ level.

When the scope (SCI) index or the coverage ( $\mathrm{COV}$ ) dimension is used as the dependent variable, determinants of forward-looking information disclosure differ, since only size (and leverage for the coverage dimension) appears as significant. When disclosure is measured in terms of scope/coverage, disclosure theories are supported but only insofar as the hypotheses that refer to size and leverage. 
When the dependent variable in the regression model is the quality index (QLI), size appears as the only determinant of an increase in disclosure quality. Moreover, the $R^{2} s$ values indicate that the model explains almost $50 \%$ of quantity, but just $10 \%$ of quality, which shows again that some of the theoretical predictions on disclosure determinants are not confirmed when specific information attributes are considered.

Nevertheless, the quality index was designed as composed of several disclosure dimensions that capture specific information attributes. The company characteristics that determine an increase in disclosure quality differ depending on the information attribute considered. The results of the estimation of the regression model by considering each of the quality index dimensions as the dependent variable are shown in Table 4.

Some of the results for the dimensions that form the quality index are inconsistent with disclosure theories, making it necessary to bear in mind that those theories refer to the total disclosure for a company, and not to specific disclosure attributes. The width (WID) dimension and its components - coverage (COV) and dispersion (DIS) - show, as expected according to disclosure theories, a positive relationship with size. This coefficient is significant at $1 \%$ for all these dimensions. However, the specific dimensions that capture information profile, which are closely associated to information richness, show unexpected results. The coefficient on size is not significant when disclosure is measured through the depth (DEP) indices, including the economic sign (ESM) and outlook profile (OTL) dimensions. This finding contradicts the disclosure theories that support a positive association between size and disclosure. Larger companies disclose information of a higher quality in terms of coverage and dispersion, but fail to provide more information about plans, decisions or actions that will affect the future development of the company or information that is useful to make forecasts. This supports our hypothesis that when more detailed attributes of the information are considered, then the existing disclosure theories may be rendered invalid.

When the components of the width dimension are considered, it is found that foreign exchange listing holds a negative relationship with forward-looking information disclosure when it is measured with the dispersion and width indices. A possible explanation is the design of this variable, which implies that only a few companies are assigned a value of 1 .

Regarding the components of the depth dimension, operating revenue growth shows a negative association with forward-looking information disclosure (outlook profile (OTL) and depth (DEP) dimensions). The coefficient of the depth index is negative (-0.260) and significant at $5 \%$. This is consistent with some theoretical arguments which claim that companies with high growth rates might be reluctant to provide voluntary information to prevent competitive disadvantages (Prencipe, 2004). However, this result is unexpected according to signalling theory, since it indicates that companies with higher growth rates provide less information of a forward-looking nature about plans, decisions, actions and less information that may be useful for forecasting purposes. The depth dimension is designed in terms of information richness, without considering information quantity or coverage. The results obtained for this measure contradict theoretical predictions, since the depth index and its components are not much explained by the selected characteristics. Different information 
attributes are explained by different determinants, as it was expected. As a consequence, different disclosure attributes must be explained with different theories.

The second objective was to examine how disclosure measure design influences the results obtained from research on disclosure determinants. To this end, two indices that measure disclosure in terms of coverage, which both pay attention to the number of topics disclosed for a given company, are compared. The two indices are the scope (SCI) index and the coverage dimension $(\mathrm{COV})$ of the quality index, which are designed in a similar fashion.

The results of the estimation of the regression model with each of these two indices as the dependent variable are shown in Table 3 . The determinants of coverage are not the same as the determinants of scope, since when measuring forward-looking information disclosure through coverage (COV), then size and leverage seem to be related to disclosure, but when it is measured with the scope index (SCI), then only size appears as significant. Moreover, the coefficient on size differs $(0.347$ when the dependent variable is the scope index and 0.581 if the coverage dimension is used). Therefore, even though similar indices are used (the coverage and the scope indices), results differ, which in turn indicates the impact that the choice of a particular disclosure measure has on this type of study.

\section{CONCLUDING REMARKS}

Research on the determinants of disclosure has so far failed to provide conclusive results. The complexity underlying disclosure measures may explain the conflicting evidence. Disclosure indices that capture diverse information attributes and have different designs coexist in this literature. We study whether the determinants of a specific information attribute differ from those that determine the disclosure of another information attribute. This being the case, disclosure theories will not unfailingly hold true, as they characterize disclosure in general terms, without making a clear distinction between specific information attributes. Moreover, we also explore the influence of disclosure index design on the results of the research on disclosure determinants. If different designs of measures that capture the same information attribute cause differences in determinants, then the evidence will highlight the need to search for measures of a more comparable nature.

An empirical analysis of forward-looking information disclosure determinants for a sample of listed Spanish companies was performed. Several disclosure indices, which measure disclosure of different information attributes (such as quantity, coverage and quality), were compared. In addition, we also compared two indices that capture the same information attribute (coverage, since this is the most commonly measured information attribute in existing literature) but which are different in design.

Our results show that size is the only determinant that is always significant, no matter which disclosure attribute is being analysed. However the determinants of information attributes of a more specific nature are different to those that influence attributes of a less specific nature. Size, leverage and growth determine information quantity. However, when disclosure is characterized in terms of quality, size is the only variable that explains disclosure. In addition, if attention is paid to the quality index components, no variable appears as a determinant of disclosure for the depth dimension, which is the dimension 
that captures information richness. Companies perceive higher costs when providing more detailed information, and the reasons for disclosing information attributes that are more related to information richness differ from those that influence the disclosure of generic information attributes. Consequently, general disclosure theories fail to hold true for all the information attributes.

Since the determinants of disclosure of some information attributes do not coincide with the determinants of another attributes, disclosure theories should therefore pay specific attention to the information attribute that is being measured. Our results help to clarify why prior evidence appears to be contradictory and to refine theoretical arguments on the reasons behind disclosure decisions. Disclosure indices should clearly define the information attribute that is captured, as it will influence the results obtained.

Furthermore, regardless of the information attribute that is measured, disclosure measure design influences results as well. Our empirical evidence indicates that results differ when two indices that capture the same information attribute, but that are different in design, are used. Empirical results are conditional upon the measure used. Therefore, care must be taken when comparing the results from disclosure studies that employ different measures of the same attribute. In terms of the implications for future research, our results highlight the need to search for a consensus on index design that would help towards comparability and enable results of a more conclusive nature to be attained. Another future development could be the study of the impact of using different disclosure indices on the effects of disclosures, such as cost of capital, analysts' forecasts and stock returns.

\section{REFERENCES}

American Institute of Certified Public Accountants (AICPA). 1973. Trueblood Report. New York.

American Institute of Certified Public Accountants (AICPA). 1994. Improving Business Reporting-A customer focus. New York.

Aнмер, K. 1996. Disclosure policy choice and corporate characteristics: a study of Bangladesh. AsiaPacific Journal of Accounting 3 (1): 183-203.

Aнmed, K., and CourTis, J. K. 1999. Associations between corporate characteristics and disclosure levels in annual reports: a meta-analysis. British Accounting Review 31: 35-61.

AlJIFRI, K., and HussaINEY, K. 2007. The determinants of forward-looking information in annual reports of UAE companies. Managerial Auditing Journal 32 (9): 881-894.

AlsAeED, K. 2005. The association between firm-specific characteristics and disclosure: the case of Saudi Arabia. Journal of American Academy of business 7 (1): 310-321.

Aвснамваult, J. J., and Aвснамваult, M. E. 2003. A multinational test of determinants of corporate disclosure. The International Journal of Accounting 38 (2): 173-194.

BAlatA, P., and BREton, G. 2005. Narratives vs. numbers in annual report: are they giving the same message? Review of Accounting and Finance 4 (2): 5-25.

Beattie, V.; McInnes, B., and Fearnley, S. 2004. A methodology for analysing and evaluating narratives in annual reports: a comprehensive descriptive profile and metrics for disclosure quality attributes. Accounting Forum 28: 205-236. 
Belsley, D.; Kun, E., and Welsch, R. 1980. Regression diagnostics: identifying influential data and sources of collinearity. New York, NY: John Wiley and Sons.

Beretta, S., and Bozzolan, S. 2005. Forward looking disclosure and financial analysts' forecasts: an international study. Working paper, Bocconi University and University of Padova.

BeretTA, S., and Bozzolan, S. 2008. Quality versus quantity: the case of forward-looking disclosure. Journal of Accounting, Auditing and Finance 23 (3): 333-375.

Beretta, S.; Bozzolan, S., and Trombetta, M. 2009. Forward looking disclosure, financial verifiability and analysts' forecasts: A study of cross-listed European firms. European Accounting Review 18 (3): 435-473.

BHoJRAJ, S. 1999. Management earnings forecasts: A theoretical and empirical analysis. Doctoral dissertation, University of Florida.

Botosan, C. A. 1997. Disclosure level and the cost of equity capital. The Accounting Review 72 (3): 323-349.

BuzBy, S. 1975. Company size, listed versus unlisted stocks, and the extent of financial disclosure. Journal of Accounting Research 13 (1): 16-37.

CANAdian Institute of Chartered Accountants (CICA). 2002. Management's discussion and analysis: Guidance on preparation and disclosure.

Cerbioni, F., and Parbonetti, A. 2007. Exploring the effects of corporate governance on intellectual capital disclosure: an analysis of European biotechnology companies. European Accounting Review 16 (4): 791-826.

Chavent, M.; Ding, Y.; Fu, L.; Stolowy, H., and Wang, H. 2006. Disclosure and determinants studies: an extension using the Divisive Clustering Method (DIV). European Accounting Review 15 (2): 181-218.

Chen, C. J. P., and JAGGI, B. 2000. Association between independent non-executive directors, family control and financial disclosures in Hong Kong. Journal of Accounting and Public Policy 19: 285-310.

Chow, C. W., and Wong-Boren, A. 1987. Voluntary financial disclosure by Mexican corporations. The Accounting Review 62 (3): 553-541.

Сооке, T. E. 1989. Disclosure in the corporate annual reports of Swedish companies. Accounting and Business Research 19 (74): 113-124. Spring.

Сооке, T. E. 1992. The impact of size, stock market listing and industry type on disclosure in the annual reports of Japanese listed corporations. Accounting and Business Research 22 (87): 229-237.

Depoers, F. 2000. A cost-benefit study of voluntary disclosure: some empirical evidence from French listed companies. European Accounting Review 9 (2): 245-263.

DuRBIN, J., and Watson, G. 1950. Testing for serial correlation in least squares regression-I. Biometrika, 37: 409-428.

Entwistle, G. M. 1999. Exploring the R\&D disclosure environment. Accounting Horizons 13 (4): 323341.

Financial Accounting Standards Board (FASB). 2001. Improving Business Reporting: Insights into Enhancing Voluntary Disclosure. Steering Committee Report. Business Reporting Research Project.

FIRTH, M. 1979. The impact of size, stock market listing, and auditors on voluntary disclosure in corporate annual reports. Accounting and Business Research Autumn: 273-280.

GARCíA, M. A., and MonTERREY, J. 1993. La revelación voluntaria en las compañías españolas cotizadas en Bolsa. Revista Española de Financiación y Contabilidad 23 (74): 53-70.

García-Meca, E., and Martínez, I. 2004. Divulgación voluntaria de información empresarial: índices de revelación. Partida Doble 157: 66-77. 
García-Meca, E.; Parra, I.; Larrán, J., and Martínez, I. 2005. The explanatory factors of intellectual capital disclosure to financial analysts. European Accounting Review 14 (1): 63-94.

GINER, B. 1995. La divulgación de información financiera: una investigación empírica. Instituto de Contabilidad y Auditoría de Cuentas. Ministerio de Economía y Hacienda, Madrid.

- 1997. The influence of company characteristics and accounting regulation on information disclosed by Spanish firms. European Accounting Review 6 (1): 45-68.

GREENE, W. 1997. Econometric analysis. Prentice Hall, International Edition.

Healy, P. M., and Palepu, K. G. 2001. Information asymmetry, corporate disclosure, and the capital markets: A review of the empirical disclosure literature. Journal of Accounting and Economics 31: 405-440.

Hossain, M.; AhMEd, K., and Godfrey, J. M. 2005. Investment opportunity set and voluntary disclosure of prospective information: A simultaneous equations approach. Journal of Business Finance and Accounting, 32: 871-907.

Hussainey, K.; SCHLEICHER, T., and WALKER, M. 2003. Undertaking large-scale disclosures studies when AIMR-FAF ratings are not available: the case of prices leading earnings. Accounting and Business Research 33 (4): 275-294.

Institute of Chartered Accountants in England and Wales (ICAEW). 1975. Corporate Report.

Institute of Chartered Accountants in England and Wales (ICAEW). 2002. Prospective financial information: Guidance for UK directors.

Jensen, M., and MeckLing, W. 1976. Theory of the firm: managerial behavior, agency costs and ownership structure. Journal of Financial Economics 3 (4): 305-360.

Kieso, D. E., and Weygandt, J. J. 1986. Intermediate Accounting. John Wiley \& Sons. New York.

KENT, P., and UNG, K. 2003. Voluntary disclosure of forward-looking earnings information in Australia. Australian Journal of Management 28 (3): 273-285.

KRIPPENDORF, K. 1980. Content analysis: an introduction to its methodology. Beverly Hills, CA: Sage Publications.

LANG, M., and LundHoLm, R. 1993. Cross-sectional determinants of analyst ratings of corporate disclosures. Journal of Accounting Research 31 (2): 246-271.

Lev, B., and Penman, S. H. 1990. Voluntary forecast disclosure, nondisclosure, and stock prices. Journal of Accounting Research 31 (2): 49-76.

LI, J.; PIKE, R., and HANNIFA, R. 2008. Intellectual capital disclosure and corporate governance structure in UK firms. Accounting and Business Research 38 (2): 137-159.

Malone, D.; Fries, J., and Jones, T. 1993. An empirical investigation of the extent of corporate financial disclosure in the oil and gas industry. Journal of Accounting, Auditing and Finance 8: 249-273.

McNally, G. M.; Eng, L. H., and Hasseldine, H. R. 1982. Corporate financial reporting in New Zeland: an analysis of user preferences, corporate characteristics and disclosure practices for discretionary information. Accounting and Business Research 13 (49): 11-20.

MeeK, G. K.; RoвerTs, C. B., and Gray, S. J. 1995. Factors influencing voluntary annual report disclosures by U.S., U.K. and continental European multinational corporations. Journal of International Business Studies 26 (3): 555-572.

Milne, M. J., and AdLer, R. W. 1999. Exploring the reliability of social and environmental disclosures content analysis. Accounting, Auditing \& Accountability Journal 12 (2): 237-256.

Моra, A., and Rees, W. 1996. Un análisis empírico sobre la práctica de la consolidación contable en las empresas españolas. Revista Española de Financiación y Contabilidad 25 (86): 161-178. 
Prencipe, A. 2004. Proprietary costs and determinants of voluntary segment disclosure: evidence from Italian listed companies. European Accounting Review 13 (2): 319-340.

RAFFouRNIER, B. 1995. The determinants of voluntary financial disclosure by Swiss listed companies. European Accounting Review 4 (2): 261-280.

RobB, S. W. G.; Single, L. E., and ZarZESki, M. T. 2001. Nonfinancial disclosures across Anglo-America countries. Journal of International Accounting 10 (1): 71-83.

RodríGuez Pérez, G. 2004. Factores explicativos de la revelación voluntaria de información sobre fuentes de ventaja competitiva empresarial. Revista Española de Financiación y Contabilidad 23 (122): 705-739.

SinghV, S., and DesaI, H. 1971. An empirical analysis of the quality of corporate financial disclosure. The Accounting Review 46: 129-138. January.

WaLlace, R. S. O.; NASER, K., and Mora, A.. 1994. The relationship between the comprehensiveness of corporate annual reports and firm characteristics in Spain. Accounting and Business Research 25 (97): 41-53.

WALLACE, R. S. O., and NASER, K. 1995. Firm-specific determinants of comprehensiveness of mandatory disclosure in the corporate annual reports of firms listed on the stock exchange of Hong Kong. Journal of Accounting and Public Policy 14 (4): 311-368.

Watts, R. L., and Zimmerman, J. L. 1986. Positive Accounting Theory. Englewood Cliffs, NJ: PrenticeHall.

Wніте, H. 1980. A heteroskedasticity-consistent covariance matrix estimator and a direct test for heteroskedasticity. Econometrica 48 (4): 817-838.

WiLLAams, S. M. 1999. Voluntary environmental and social accounting disclosure practices in the AsiaPacific region: An international empirical test of political economy theory. The International Journal of Accounting 34 (2): 209-238. 



\title{
Discussion
}

\section{On}

\section{Disclosure theories and disclosure measures (by F. Bravo Urquiza, M. C. Abad Navarro and M. Trombetta)}

\author{
Juan Manuel García Lara. Universidad Carlos III de Madrid
}

\section{WHAT IS DISCLOSURE QUALITY?}

In the presence of information asymmetries, potential investors cannot properly evaluate the expected profitability and risk of the available investment opportunities. Firms provide information to reduce the adverse effects of these information asymmetries (inefficient pricing and adverse selection problems, as described by Akerlof, 1970). This provision of information from firms to the potential providers of capital funds is done through the financial statements and also through other communication channels. An impressive amount of literature has analysed how the information reported compulsorily in the financial statements should be to reduce the problems created by information asymmetries. One example of this literature is the large stream of studies about whether accounting numbers should be more or less conservative (LaFond \& Watts, 2008, García Lara, García Osma \& Penalva, 2011). Similarly, there are many studies analysing whether and how voluntary disclosure contributes to reduce adverse selection problems. A recent example of this voluntary disclosure literature is Francis, Nanda \& Olsson (2008), who study whether voluntary disclosure contributes to decrease cost of capital. An increased cost of capital is one of the clearest examples of the deadweight losses introduced by information asymmetries.

Even if the problems of adverse selection are resolved through the ex-ante provision of information, there is still an unresolved issue. Once that investors allocate their funds to the firms, current investors will require information about firm's activities to avoid being expropriated by the managerial team or the dominating shareholder. Consequently, besides the role of (accounting) information to resolve problems related to the allocation of resources in the economic system, accounting information plays also a role in resolving agency conflicts between the different parties in the firm (Jensen \& Meckling, 1976). This provision of information to monitor managerial decisions can also be done through the financial statements, and also through other voluntary channels. Prior accounting research has analysed which should be the desirable characteristics of the information included in the financial statements to permit a better monitoring over managers' decisions. Recent examples of this literature include García Lara, García Osma \& Penalva (2009) or Biddle, Hilary \& Verdi (2009). Regarding disclosure, there is also a large stream of research stu- 
dying the role of disclosure to reduce agency costs. For a recent example, see Hope \& Thomas (2008).

Healy and Palepu (2001) describe in more detail these two roles of voluntary disclosure to decrease adverse selection and agency problems. Given these two roles, I believe that, from a theoretical viewpoint, voluntary disclosure could be labeled as being of high quality when it contributes to reduce adverse selection problems and agency costs. One related issue to consider as well is that, in certain scenarios, disclosure of information that reduces agency costs might not be optimal. These scenarios are basically two: $a$ ) if disclosure increases proprietary costs beyond the reduction in agency costs ${ }^{(1)}$, and $b$ ) if disclosure leads to excess monitoring and this excess monitoring drives managers into taking inefficient operating decisions that decrease firm value beyond the reduction in agency costs (Hermalin \& Weisbach, 2009).

\section{EMPIRICAL MEASURES OF DISCLOSURE QUALITY}

Measuring the quality of disclosure is a difficult task, and most of the empirical research on voluntary disclosure has used measures that are closer to quantity rather than to quality. A good example is the study of Francis et al. (2008). They analyse whether voluntary disclosure reduces cost of capital. Once they control for earnings quality they fail to find any relation between voluntary disclosure and cost of capital. They measure disclosure using an index that they create analysing whether the firm discloses 25 items of information. They assign a value of 1 or 0 for each item of information disclosed or not disclosed. For example, they analyse whether the firm provides a forecast of sales. If the firm provides the forecast, they add 1 point to the index. They do the same with other 24 information items including forecasts of cash flows, forecasts of profits, number of employees, etc... The issue with their index is that it captures disclosure quantity, and not disclosure quality. That is, we cannot know whether the sales forecast is really contributing to decrease information asymmetries, as it may even introduce additional noise if it is not reflecting the true expectations. This is so because an opportunistic manager can use forecasts to create false expectations about future outcomes. Given that their index captures quantity, and it is not clear that it captures quality, the link between their proxy and cost of capital is not clear either, and this could partly explain why they fail to find a relation between voluntary disclosure and cost of capital.

Several studies have proposed different ways of disentangling disclosure quantity from disclosure quality. One valuable example is $\mathrm{Li}$ (2010). In her study on how product market competition impacts voluntary disclosure, she uses the accuracy of the management forecasts of earnings and capital expenditures as a proxy for the quality of voluntary disclosure of forward looking information. More accurate forecasts of earnings and capital expenditures are expected to decrease information asymmetries between managers and current and potential shareholders, thus contributing to reduce adverse selection problems and to improve the monitoring over managers. Therefore, to contribute to improve disclosure

(1) There is an extensive literature on the proprietary costs of disclosure. See, for example, Wagenhofer (1990). 
quality it is not only necessary that the firm provides a forecast, but also that the forecast is accurate.

Another example is Blanco, García Lara \& Tribó (2010). They study whether improved voluntary segment disclosure contributes to decrease cost of capital. Contrary to Francis et al. (2008) they find that improved segment disclosure contributes to decrease cost of capital beyond the decrease due to improved earnings quality. As a proxy for the quality of segment disclosures they use the residuals of a model where they explain the quantity of segment disclosures on business and geographic diversification, information asymmetries and controls. Firms providing more details than expected about their segments (larger residuals) are expected to contribute more to reduce information asymmetries, and are expected to facilitate the estimation of future cash flows. Consequently, they interpret the residuals of the regression as a proxy for disclosure quality. They further find that the segment disclosure quantity is just a proxy for firm diversification, and consequently, that firms with a larger quantity of segment disclosures are not necessarily those facing less information asymmetries.

\section{CONCLUSIONS}

An important part of the research questions in the empirical disclosure literature link disclosure quality, not disclosure quantity, to some economic outcomes (profitability, access to and cost of capital funds, corporate governance, etc...). Both Li (2010) and Blanco et al. (2010) find ways to ascertain whether the information disclosed contributes to improve the information environment of the firm. That is, they successfully disentangle disclosure quality from disclosure quantity. I believe this should be the way forward in this stream of literature, and that researchers should struggle to find their own ad-hoc ways to disentangle disclosure quality from disclosure quantity in their research settings.

\section{REFERENCES}

Aваd, C.; Bravo, F., and Trombetта, M. 2010. Disclosure theories and disclosure measures. Revista Española de Financiación y Contabilidad. This issue.

AKERLOF, G. 1970. The market for lemons: quality uncertainty and the market mechanism. Quarterly Journal of Economics 84 (3): 488-500.

Biddle, G. C.; Hilary, G., and Verdi, R. S. 2009. How does financial reporting quality improve investment efficiency? Journal of Accounting and Economics 48: 112-131.

Blanco, B.; García Lara, J. M., and Tribó, J. A. 2010. The complementarity between earnings quality and segment disclosure, and its effect on cost of capital. Working paper. Universidad Carlos III de Madrid.

FrAncIS, J.; NANDA, D. J., and OLSSON, P. 2008. Voluntary disclosure, earnings quality and costs of capital. Journal of Accounting Research 46: 53-99.

García Lara, J. M.; García Osma, B., and Penalva, F. 2009. Accounting conservatism and corporate governance. Review of Accounting Studies 14 (1): 161-201.

García Lara, J. M.; García Osma, B. and Penalva, F. 2011. Conditional conservatism and cost of capital. Review of Accounting Studies 16(2). Forthcoming. 
Healy, P., and PAPELU, K. 200. Information asymmetry, corporate disclosure, and the capital markets: A review of the empirical disclosure literature. Journal of Accounting and Economics 31: 485-520.

Hermalin, B. E., and Weisbach, M. S. 2009. Information disclosure and corporate governance. Working paper. University of California.

Hope, K. O., and Thомаs, W. B. 2008. Managerial empire building and firm disclosure. Journal of Accounting Research 46 (3): 591-626.

Jensen, M. C. \& Meckling, W. H. 1976. Theory of the firm: Managerial behaviour, agency costs and ownership structure. Journal of Financial Economics 3(4): 305-360.

LAFond, R., and WATTS, R. L. 2008. The information role of conservatism. The Accounting Review 83 (2): 447-478.

LI, X. 2010. The impacts of product market competition on the quantity and quality of voluntary disclosures. Review of Accounting Studies, Forthcoming.

WAGENHOFER, A. 1990. Voluntary disclosure with a strategic opponent. Journal of Accounting and Economics 12: 341-363. 